\title{
BMJ Open Prevalence of hypertension at high altitude: cross-sectional survey in Ladakh, Northern India 2007-2011
}

\author{
Tsering Norboo, ${ }^{1}$ Tsering Stobdan, ${ }^{2}$ Norboo Tsering, ${ }^{1}$ Norboo Angchuk, ${ }^{3}$ \\ Phunsog Tsering, ${ }^{3}$ Iqbal Ahmed, ${ }^{3}$ Tsewang Chorol, ${ }^{3}$ Vijay Kumar Sharma, ${ }^{4}$ \\ Prasanna Reddy, ${ }^{5}$ Shashi Bala Singh, ${ }^{5}$ Yumi Kimura, ${ }^{6}$ Ryota Sakamoto, ${ }^{7}$ \\ Eriko Fukutomi, ${ }^{6}$ Motonao Ishikawa, ${ }^{8}$ Kuniaki Suwa, ${ }^{8}$ Yasuyuki Kosaka, ${ }^{9}$ \\ Mitsuhiro Nose, ${ }^{6}$ Takayoshi Yamaguchi, ${ }^{10}$ Toshihiro Tsukihara, ${ }^{11}$ \\ Kozo Matsubayashi, ${ }^{6}$ Kuniaki Otsuka, ${ }^{7}$ Kiyohito Okumiya ${ }^{6,12}$
}

To cite: Norboo T,

Stobdan T, Tsering N, et al. Prevalence of hypertension at high altitude: cross-sectional survey in Ladakh, Northern India 2007-2011. BMJ Open 2015:5:e007026

doi:10.1136/bmjopen-2014007026

- Prepublication history for this paper is available online. To view these files please visit the journal online (http://dx.doi.org/10.1136/ bmjopen-2014-007026).

Received 26 October 2014 Revised 14 January 2015 Accepted 26 January 2015

CrossMark

For numbered affiliations see end of article.

Correspondence to Dr Tsering Norboo; norboonsn@yahoo.com

\section{ABSTRACT}

Objective: Prevalence of hypertension was examined in a widely dispersed $\left(45110 \mathrm{~km}^{2}\right)$ representative group of Ladakhi in Northern India. The influence of hypoxic environment of wide-ranged altitude (2600$4900 \mathrm{~m}$ ) and lifestyle change on hypertension was studied.

Methods: 2800 participants (age 20-94 years) were enrolled. Systolic blood pressure $\geq 140 \mathrm{~mm} \mathrm{Hg}$ and/or diastolic blood pressure of $\geq 90 \mathrm{~mm} \mathrm{Hg}$ and/or taking current anti-hypertensive medicine was defined as hypertension. Height and weight for body mass index and $\mathrm{SpO}_{2}$ were examined. The rural population comprised six subdivisions with a distinct altitude, dietary and occupational pattern. Participants in the urban area of Leh consist of two groups, that is, migrants settled in Leh from the Changthang nomadic area, and dwellers born in Leh. The prevalence of hypertension in the two groups was compared with that in the farmers and nomads in rural areas. The effects of ageing, hypoxia, dwelling at high altitude, obesity, modernised occupation, dwelling in an urban area, and rural-to-urban migration to hypertension were analysed by multiple logistic regression.

Results: The prevalence of hypertension was $37.0 \%$ in all participants and highest in migrants settled in Leh $(48.3 \%)$, followed by dwellers born in Leh town $(41.1 \%)$ compared with those in rural areas (33.5). The prevalence of hypertension in nomads (all: $27.7 \%$, Tibetan/Ladakhi: 19.7/31.9\%)) living at higher altitude (4000-4900 m) was relatively low. The associated factors with hypertension were ageing, overweight, dwelling at higher altitude, engagement in modernised sedentary occupations, dwelling in urban areas, and rural-to-urban migration. The effects of lifestyle change and dwelling at high altitude were independently associated with hypertension by multivariate analysis adjusted with confounding factors.

Conclusions: Socioeconomic and cultural factors play a big role with the effect of high altitude itself on high prevalence of hypertension in highlanders in Ladakh.

\section{Strengths and limitations of this study}

- This study examined most of the socioeconomic environmental factors known to influence hypertension in a population of different distinct geographical subdivisions of a high-altitude region. Though we did not carry out a nutritional survey in all the participants, overweight was a decisive factor for hypertension according to lifestyle change.

- This study showed the influence of ageing, overweight, modernised sedentary occupations, ruralto-urban migration and dwelling in urban areas to hypertension as well as the effect of altitude by multivariate analysis.

- This study did not look into the genetic factors, as environmental and genetic factors may contribute to regional and racial variations of blood pressure and the prevalence of hypertension.

\section{INTRODUCTION}

Systemic arterial hypertension at high altitude has evoked great interest among high-altitude researchers as well as in sojourners and natives. There have been conflicting reports with investigators generally reporting a slight increase in the blood pressure level soon after arrival at high altitude ${ }^{12}$ and investigators reporting no such change ${ }^{34}$ or a decrease followed by an increase. ${ }^{56}$ There is no standard way of treating hypertension at high altitude for sojourners till now. ${ }^{7}$ Similar contradictory views also exist between the investigators of the two high-altitude continents regarding the blood pressure status of the high-altitude natives. Studies done in Spiti India (4000 m) show a lower prevalence of hypertension. ${ }^{9}$ Andean residents are reported to have low prevalence of hypertension ${ }^{1} 1011$ while the prevalence of hypertension in Tibet Lhasa was found to be higher than that of Han 
migrants residing in Tibet. ${ }^{12}$ Recent reports showed that the prevalence of hypertension was higher in Tibetan highlanders ${ }^{13} 14$ than in Chinese lowlanders. ${ }^{15}$

The risk of developing hypertension may depend on socioeconomic factors, as well as geographic and racial differences. It is in the backdrop of this difference in opinion that we planned this study in Ladakh, one of the highest inhabited regions in the northernmost part of India. The population of the two districts of Ladakh (Leh and Kargil) was about 270000 (Leh: 130000 , Kargil: 140000 ) in 2011 by Census. ${ }^{16} 77 \%$ of the population in Leh are Buddhists and $80 \%$ of the Kargil population are Muslims. Spread over $45110 \mathrm{~km}^{2}$, sandwiched between Karakoram in the north and Trans-Himalaya in the south and $80 \%$ comprising of a rural population with many villages high up in the mountains remaining inaccessible during winter, logistics for conducting a comprehensive epidemiological study representative of the whole population is formidable. The purpose of the study is twofold: first, to determine the prevalence of hypertension in different geographical subdivisions of this widely dispersed high-altitude district (from a median high $2500 \sim$ to very high $\sim 4500 \mathrm{~m}$ ), and second, which factors among the altitude, occupation, socioeconomic and lifestyle play a predominant role in association with hypertension.

\section{METHODS}

This cross-sectional epidemiological study was carried out from 2007 to 2011. A total of 2800 participants aged between 20 and 94 years were examined. Figure 1 shows the map of Ladakh region showing all the villages in the subdivisions where the study was conducted. A two-stage stratified sampling method was used to select a representative sample of the adult population over 20 years of age. The population was first stratified as urban versus rural and then in the rural sector into six geographical areas (subdivisions). Each geographical subdivision has different characteristics in altitude, occupation, dietary habits and socioeconomic conditions as well as separate administrative blocks (table 1). Migrants from the rural

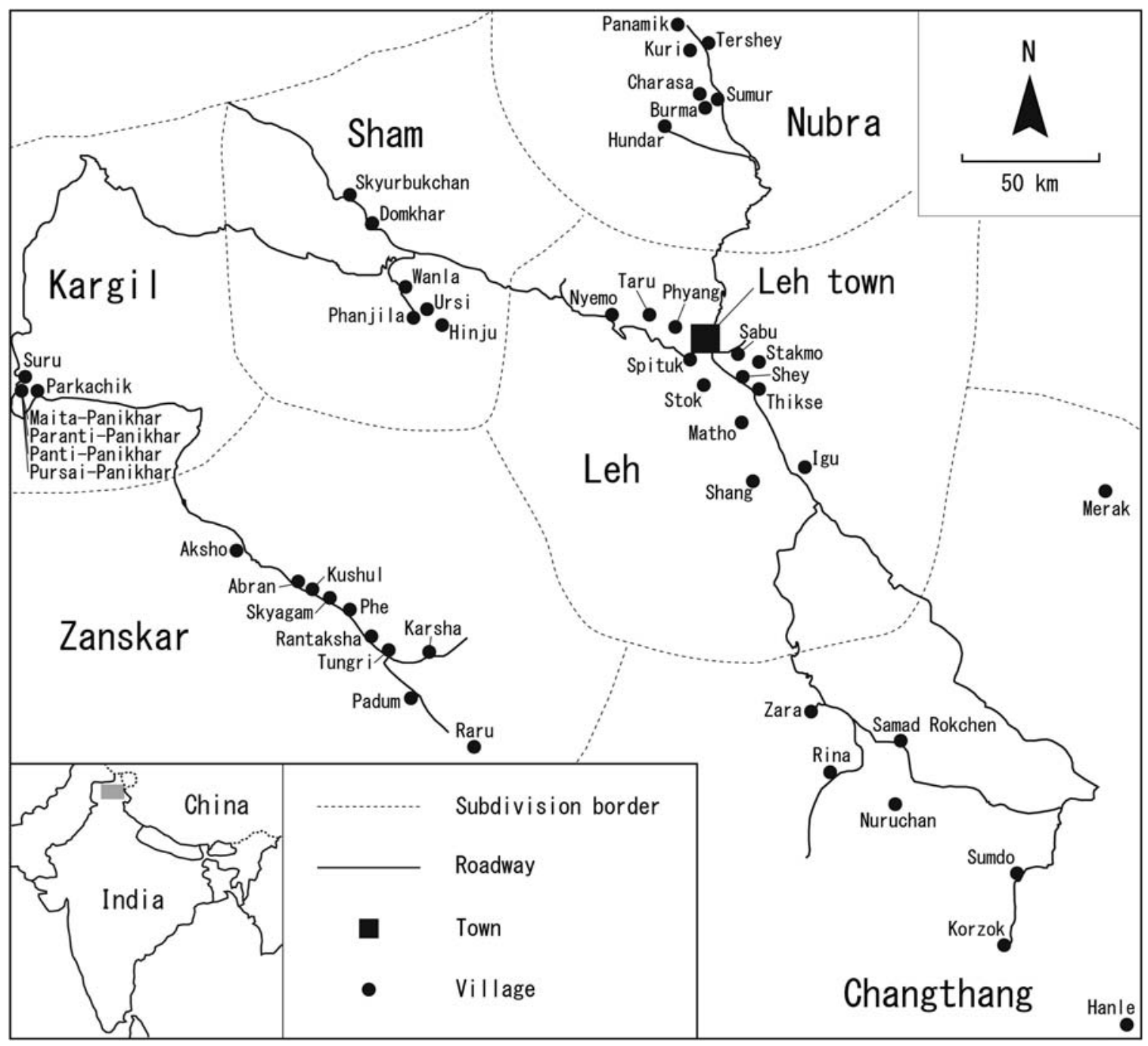

Figure 1 Map of Ladakh Region showing all the field sites. The map of Ladakh region showing all the villages in the subdivisions where the study was conducted. 
Table 1 Characteristics of the subdivisions

\begin{tabular}{llll}
\hline Urban/rural & Subdivision & Altitude (metres above MSL) & Livelihood \\
\hline Urban & Leh town (including colonies of migrants) & $3300-3600$ & Urban lifestyle \\
Rural & Leh block villages & $3000-3700$ & Farmer \\
& Nubra & $2600-3000$ & Farmer \\
& Kargil (Panikhar and Parkachik) & $2600-3100$ & Farmer \\
& Sham & $2700-3900$ & Farmer \\
& Zanskar & $3500-3900$ & Farmer and cattle rearing \\
& Changthang & $4000-4900$ & Livestock rearing nomads \\
\hline MSL, mean sea level. & &
\end{tabular}

population now settled in the Leh town subdivision since the 1970 s were included in the urban population as they have adopted a lifestyle similar to the city dwellers. The Tata Institute of Social Sciences Mumbai (TISS) and Ladakh Autonomous hill development council (LAHDC) conducted a house-to-house survey of the total population of Leh (urban population) in 2007 for developing Ladakhi villages in the region. ${ }^{17}$ Since the data from this census were the latest, we corrected and used this population survey list (age group 20-90 years) to draw our sample of urban population for the study. The list of 2000 eligible participants was representative of the age and gender structure of a Ladakhi family and they were invited as the volunteer participants to the research centre in Leh town. In the rural villages, all men and women aged 20 years or more were announced in the collaboration of health staff and village leaders. We carried out health checks on the volunteer participants in health centres or community halls in the rural villages.

There were no criteria for exclusion except absentees and critical and terminal illness patients who cannot report to the study centre to complete the study. Participants in Leh town subdivision were classified into two groups, that is, migrants settled in Leh town from Changthang area, and dwellers in Leh town. The former consisted of Tibetan and Ladakhi nomads. The latter consisted of Tibetans born in Leh, and other Ladakhi people, almost of whom were born in Leh, including some migrants from rural areas (non-Changthang).

The rural population was subdivided into six subdivisions as each subdivision had distinct characteristics which could influence the outcome.

Leh block subdivision comprises nearly 12 villages within $40 \mathrm{~km}$ of Leh town at an altitude varying between 3000 and $3700 \mathrm{~m}$. The occupations of those living here are a mix of farming and modernised sedentary work. Nubra subdivision is in the north of Ladakh about $120 \mathrm{~km}$ from Leh after crossing Khardong Pass $(5400 \mathrm{~m})$, one of the highest motorable roads in the world. We studied the population of seven villages here. The subdivision is located on the banks of Shyok and Nubra rivers between the Karokoram and Ladakh ranges of mountains. People are predominantly farmers and the altitude of the valley generally is around 2600-3000 m. Kargil subdivision (Panikhar and Parkachik) is a green belt in Kargil district and is a fertile farming area on the Suru river. However, fruit trees are not cultivated here. The population is mainly Muslim and the altitude is $2600-3100 \mathrm{~m}$. We studied the population of six villages representative of this subdivision. Sham (Khalse) subdivision is wide-ranged in altitude (2700-3900 m), generally more fertile and many of the villages have fruit trees like apricot, apple and almond. We studied six representative villages in this subdivision. Zanskar subdivision is a remote region on the trans Himalayan range of mountain which remains closed from the rest of the world for 6 months in a year due to heavy snowfall. Though people do farming, yet the harsh weather is not conducive for productive farming. Fresh fruit and vegetables are very meagre here. People rear cattle, which forms their secondary source of income by selling dairy products. The altitude of the subdivision is $3500-3900 \mathrm{~m}$. We studied 10 villages representative of this subdivision. Changthang subdivision is the biggest and highest plateau (Altitude 4000-4900 m). The population is generally nomadic, moving from pasture to pasture every 3 months along with their cattle and livestock and living in Yak wool woven tents. Life is very hard for them because of the high altitude and severe cold. Farming is not possible, and fresh fruit and vegetables fruits are not available to them throughout the year. Meat, barley flour and local tea are their staple diet. We studied six villages representative of the subdivision.

The occupation was interviewed from all the participants and classified into four groups: farmer, nomad, sedentary worker and others (housewife, manual labourer, monk, retired sedentary worker and no job). A full-time housewife was regarded as a housewife. A housewife who also worked as a nomad or farmer was classified as a nomad or farmer. People engaged in work closely associated with an urban lifestyle are classified into sedentary workers consisting of office worker, business person, shopkeeper, taxi driver, government officer, travel agent, teacher and so on.

The procedure for obtaining informed consent was approved by the Institutional review board of the Ladakh institute of prevention and the District ethical committee, Leh, Ladakh and Research Institute for Humanity and Nature, Kyoto, Japan. The participants attended the village medical aid centre or the village community centre. Anthropometric measurements including weight 
and height were obtained using standard techniques. The body mass index (BMI) was calculated using the formula, weight $(\mathrm{kg}) /(\text { height }(\mathrm{m}))^{2}$. Blood pressure was measured in an arm using an automatic device (HEM 7000; OMRON Life Science Co. Ltd, Kyoto, Japan) based on the cuff oscillometric principle, and its accuracy has been validated in previous studies. ${ }^{18-20}$ Oxyhaemoglobin saturation $\left(\mathrm{SpO}_{2}\right)$ was measured by a pulse oximeter (PULSOX-300; KONICA MINOLTA Co. Ltd, Tokyo, Japan). Blood pressure and $\mathrm{SpO}_{2}$ were measured twice after taking at least a 5 min rest in a sitting position and the mean of systolic blood pressure (SBP), diastolic blood pressure (DBP) and $\mathrm{SpO}_{2}$ was calculated. SBP $\geq 140 \mathrm{~mm} \mathrm{Hg}$ and/or DBP of $\geq 90 \mathrm{~mm} \mathrm{Hg}$ and/or taking current anti-hypertensive medicine was defined as hypertension. ${ }^{21}$ The mean rate of current antihypertensive medication was $2.1 \%$.

The age of the participants was confirmed with reference to a carefully prepared cross tabulation correlating their date of birth with the animal year, which the rural population always remembered, and to historical sentinel events in case of elderly participants.

\section{Statistical analysis}

$\chi^{2}$ Test, Student's t-test and one-way analysis of variance were conducted for the analysis of the prevalence rate of hypertension or overweight (BMI $\geq 25$ ), mean SBP, DBP, $\mathrm{BMI}$ and $\mathrm{SpO}_{2}$. The associations of hypertension with the above confounding factors including altitude, ageing, sex, obesity, occupation and dwelling area were analysed by multiple logistic regression. Hypertension as the dependent variable was defined as $\mathrm{SBP} \geq 140 \mathrm{~mm} \mathrm{Hg}$ and/or DBP of $\geq 90 \mathrm{~mm} \mathrm{Hg}$ and/or taking current antihypertensive medicine. ${ }^{21}$ SPSS V.17.0 (SPSS Inc., Chicago, Illinois, USA) was used for the analysis. A statistically significant level was $\mathrm{p}<0.05$.

\section{RESULTS}

A total of 2800 participants aged between 20 and 94 years were examined between 2007 and 2011.

Table 2 shows the characteristics of all variables and those associated with hypertension were overviewed. We found a $37.0 \%$ crude prevalence rate in the total Ladakhi population of both men and women. Male and older people, as well as those with overweight, had more prevalence of hypertension, but $\mathrm{SpO}_{2}$ was not associated with hypertension. Dwelling at an altitude of 3000$3999 \mathrm{~m}$ had more prevalence of hypertension compared with altitude below 3000 or above $4000 \mathrm{~m}$. People dwelling in urban areas had more prevalence of hypertension compared with those in rural areas. Nomads had lower prevalence of hypertension compared with farmers or sedentary workers.

Table 3 shows the participants surveyed and the prevalence rates of hypertension, mean SBP, DBP, BMI, rate of overweight (BMI $\geq 25$ ) and mean $\mathrm{SpO}_{2}$ according to sex and age groups in Ladakh region. Prevalence rates of hypertension, mean SBP and DBP increased significantly with ageing in men and women. Up to the age of 60 years, men tend to have higher blood pressure than women; however, there were no significant differences between men and women aged 60 years or above. The prevalence of overweight was highest $(28.5 \%)$ in the 40-59 age group and men had a higher prevalence rate of overweight than women up to 75 years. Mean $\mathrm{SpO}_{2}$ decreased significantly with ageing in both men and women.

Table 4 shows the crude and age-standardised prevalence rates of hypertension, and overweight (\%) in seven subdivisions in Ladakh region in each age group. As the mean age was different among the participants of the seven subdivisions (ANOVA, analysis of variance; $\mathrm{p}<0.0001)$, age-standardised prevalence rates were calculated.

Leh town subdivision, which is inhabited by an urban population, had a higher crude prevalence rate of hypertension $(43.4 \%)$ with age-standardised prevalence rate $(45.5 \%)$ than any other subdivisions comprising a rural population (crude; 24.3-39.1, age-standardised; 24.6-36.8) (ANOVA, $\mathrm{p}<0.0001$ ). The prevalence of hypertension, especially in the younger age group of 4059 years, was extremely high in Leh town $(41.6 \%)$ compared with other rural subdivisions (19.6-30.7\%) (ANOVA, $\mathrm{p}<0.0001$ ). Also in the old population above 60 years, the prevalence of hypertension was highest in Leh town $(61.7 \%)$ compared with other rural subdivisions $(34.1-56.0 \%$ ) (ANOVA, $\mathrm{p}=0.0001$ ). There was no significant difference in prevalence of hypertension in the young age group of 20-39 among the seven subdivisions (ANOVA; ns, not significant). Prevalence rates of hypertension increased significantly with ageing in all subdivisions (ANOVA, $\mathrm{p}<0.01 \sim \mathrm{p}<0.0001$ ) except Kargil. Prevalence of overweight $(\mathrm{BMI} \geq 25)$ was highest in the middle age group of 40-59 in Leh town subdivision.

Table 5 shows the prevalence rate of hypertension at different altitude levels according to age and occupation group. Up to the altitude of $4000 \mathrm{~m}$, the prevalence of hypertension rose with altitude and the participants surveyed at altitude ranging from 3500 to $3999 \mathrm{~m}$ had a higher prevalence rate of hypertension $(40.8 \%)$ than the other altitude ranges in all participants (ANOVA, $\mathrm{p}<0.0001)$. In the age group of $20-59$ years, people at altitude ranging from 3000 to $3499 \mathrm{~m}$ had a higher prevalence rate of hypertension than others, while in the age group of 60-74 years, up to the altitude of $4499 \mathrm{~m}$, the prevalence rate of hypertension rose with altitude, and people at altitude ranging from 4000 to $4499 \mathrm{~m}$ had the highest prevalence rate of hypertension $(55.8 \%)$ (ANOVA, $\mathrm{p}<0.05)$. In the age group of 75 years and more, the prevalence of hypertension was highest and there was no difference among altitude levels.

According to occupation group, the prevalence of hypertension rose closely with altitude remarkably in agriculture $(p<0.001)$, mildly in sedentary workers $(p=0.09)$ and insignificantly in nomads. 
Table 2 Characteristics of all variables and those associated with hypertension in Ladakh region

\begin{tabular}{|c|c|c|c|c|}
\hline & All & Hypertension (+) & Hypertension (-) & p Value \\
\hline $\mathrm{n}$ & 2800 & 1037 & 1763 & \\
\hline Per cent & & $37.0(35.2$ to 38.8$)$ & $63.0(61.2$ to 64.8$)$ & \\
\hline Male (\%) & 44.3 (41.8 to 46.8$)$ & 46.9 (43.9 to 49.9$)$ & $42.8(40.5$ to 45.1$)$ & 0.03 \\
\hline age (years) & $53.8 \pm 15.0$ & $60.1 \pm 13.8$ & $50.1 \pm 14.4$ & $<0.0001$ \\
\hline weight (kg) & $55.3 \pm 11.1$ & $57.4 \pm 12.2$ & $54.1 \pm 10.2$ & $<0.0001$ \\
\hline BMI & $22.6 \pm 3.6$ & $23.6 \pm 3.9$ & $22.0 \pm 3.3$ & $<0.0001$ \\
\hline Overweight $(\mathrm{BMI} \geq 25)(\%)$ & 24.4 (22.8 to 26.0$)$ & 34.9 (32.0 to 37.8$)$ & 18.2 (16.4 to 20.0$)$ & $<0.0001$ \\
\hline $\mathrm{SpO}_{2}(\%)$ & $89.7 \pm 5.2$ & $89.5 \pm 5.4$ & $89.8 \pm 5.2$ & ns \\
\hline $\mathrm{SpO}_{2}<89(\%)$ & 32.5 (30.8 to 34.2$)$ & 32.1 (29.3 to 34.9 ) & 32.7 (30.5 to 34.9 ) & ns \\
\hline $\mathrm{SBP}(\mathrm{mm} \mathrm{Hg})$ & $130.9 \pm 23.2$ & $153.8 \pm 19.9$ & $117.5 \pm 11.7$ & $<0.0001$ \\
\hline $\mathrm{DBP}(\mathrm{mm} \mathrm{Hg})$ & $82.5 \pm 13.4$ & $94.6 \pm 11.2$ & $75.4 \pm 8.5$ & $<0.0001$ \\
\hline \multirow[t]{2}{*}{ Altitude (m) } & $3514.4 \pm 432.2$ & $3524.6 \pm 388.6$ & $3508.3 \pm 455.9$ & ns \\
\hline & n & & & \\
\hline Altitude $(n=2800), m$ & & Per cent & Per cent & $<0.0001$ \\
\hline 2500-2999 & 417 & 27.1 (22.8 to 31.4$)$ & 72.9 (68.6 to 77.2$)$ & \\
\hline 3000-3499 & 428 & 37.4 (32.8 to 42.0$)$ & 62.6 (58.0 to 67.2$)$ & \\
\hline 3500-3999 & 1604 & 40.8 (38.4 to 43.2$)$ & 59.2 (56.8 to 61.6$)$ & \\
\hline 4000-4499 & 174 & 30.5 (23.7 to 37.3$)$ & 69.5 (62.7 to 76.3$)$ & \\
\hline $4500-4999$ & 177 & 32.2 (25.3 to 39.1$)$ & 67.8 (60.9 to 74.7$)$ & \\
\hline Dwelling area $(n=2800)$ & & Per cent & Per cent & $<0.0001$ \\
\hline Rural areas & 1798 & 33.5 (31.3 to 35.7$)$ & 66.5 (64.3 to 68.7$)$ & \\
\hline Leh block (3000-3700 m) & 349 & 33.0 (28.1 to 37.9$)$ & 67.0 (62.1 to 71.9$)$ & \\
\hline Nubra (2600-3000 m) & 248 & 27.8 (22.2 to 33.4$)$ & 72.2 (66.6 to 77.8$)$ & \\
\hline Kargil (2600-3100 m) & 115 & $24.3(16.5$ to 32.1$)$ & $75.7(67.9$ to 83.5$)$ & \\
\hline Sham (2700-3900 m) & 451 & 39.2 (34.7 to 43.7 ) & 60.8 (56.3 to 65.3$)$ & \\
\hline Zanskar (3500-3900 m) & 284 & 36.3 (30.7 to 41.9$)$ & 63.7 (58.1 to 69.3 ) & \\
\hline Changthang $(4000-4900 \mathrm{~m})$ & 351 & 31.3 (26.4 to 36.2$)$ & 68.7 (63.8 to 73.6$)$ & \\
\hline Urban area: Leh town $(3300-3600 \mathrm{~m})$ & 1002 & $43.4(40.3$ to 46.5$)$ & 56.6 (53.5 to 59.7$)$ & \\
\hline Dwellers in Leh town* & 683 & 41.1 (37.4 to 44.8$)$ & 58.9 (55.2 to 62.6$)$ & \\
\hline Migrants from Changthang & 319 & 48.3 (42.8 to 53.8$)$ & 51.7 (46.2 to 57.2$)$ & \\
\hline Occupation $(n=2800)$ & & Per cent & Per cent & $<0.0001$ \\
\hline Farmer & 1247 & 36.6 (33.9 to 39.3$)$ & $63.4(60.7$ to 66.1$)$ & \\
\hline Nomad & 220 & $27.7(21.8$ to 33.6$)$ & $72.3(66.4$ to 78.2$)$ & \\
\hline Sedentary worker & 549 & 37.3 (33.3 to 41.3$)$ & 62.7 (58.7 to 66.7$)$ & \\
\hline Others & 784 & 40.2 (36.8 to 43.6$)$ & 59.8 (56.4 to 63.2$)$ & \\
\hline Housewife & 325 & 42.5 (37.1 to 47.9$)$ & 57.5 (52.1 to 62.9$)$ & \\
\hline Manual labourer & 63 & $14.3(5.7$ to 22.9$)$ & 85.7 (77.1 to 94.3$)$ & \\
\hline Monk & 157 & $36.9(29.4$ to 44.4$)$ & 63.1 (55.6 to 70.6$)$ & \\
\hline No job & 138 & 44.2 (35.9 to 52.5$)$ & 55.8 (47.5 to 64.1$)$ & \\
\hline Retired sedentary & 101 & 48.5 (38.8 to 58.2$)$ & 51.5 (41.8 to 61.2$)$ & \\
\hline
\end{tabular}

Mean \pm SD, \% (95\% Cl).

$\mathrm{p} ; \chi^{2}$ Test for the comparison of the rate of variables, and Student's $t$ test for the comparison of the mean of variables between hypertension and non-hypertension.

${ }^{*}$ Almost born in Leh with some migrants from no-Changthang areas.

$\mathrm{BMI}$, body mass index; DBP, diastolic blood pressure; ns, not significant; SBP, systolic blood pressure; $\mathrm{SpO}_{2}$, oxyhaemoglobin saturation measured by a pulse oximeter.

Table 6 shows the prevalence rate of hypertension at different altitude levels in each subdivision. In the only Sham subdivision, where altitude ranging is as wide as $2700-3900 \mathrm{~m}$, the prevalence rate of hypertension increased $(29.1,36.2,46.4 \%, \mathrm{p}=0.0067)$ in accord with the elevation of altitude (2500-2999, 3000-3499, 3500$3999 \mathrm{~m})$ in spite of the decrease in overweight $(23.3$, $18.9,12.6 \%, \mathrm{p}=0.040$ ) with the altitude. In the other subdivisions, there was no difference in the prevalence rate of hypertension among different altitudes.
Table 7 shows the prevalence rate of hypertension and overweight in people with different occupations. In the age group of 40-59 years, sedentary workers had the highest prevalence of hypertension $(48.3 \%)$ and obesity $(43.9 \%)$, while nomads (hypertension/obesity; 19.6\%/22.5\%) and manual labourers $(11.3 \% / 20.8 \%)$ had a lower prevalence of hypertension compared with other workers (27.3$36.1 \% / 20.1-61.1 \%$ ) (ANOVA, $\mathrm{p}<0.0001$ ). In the other age groups, there was no or little significant difference in the prevalence of hypertension among different occupations. 


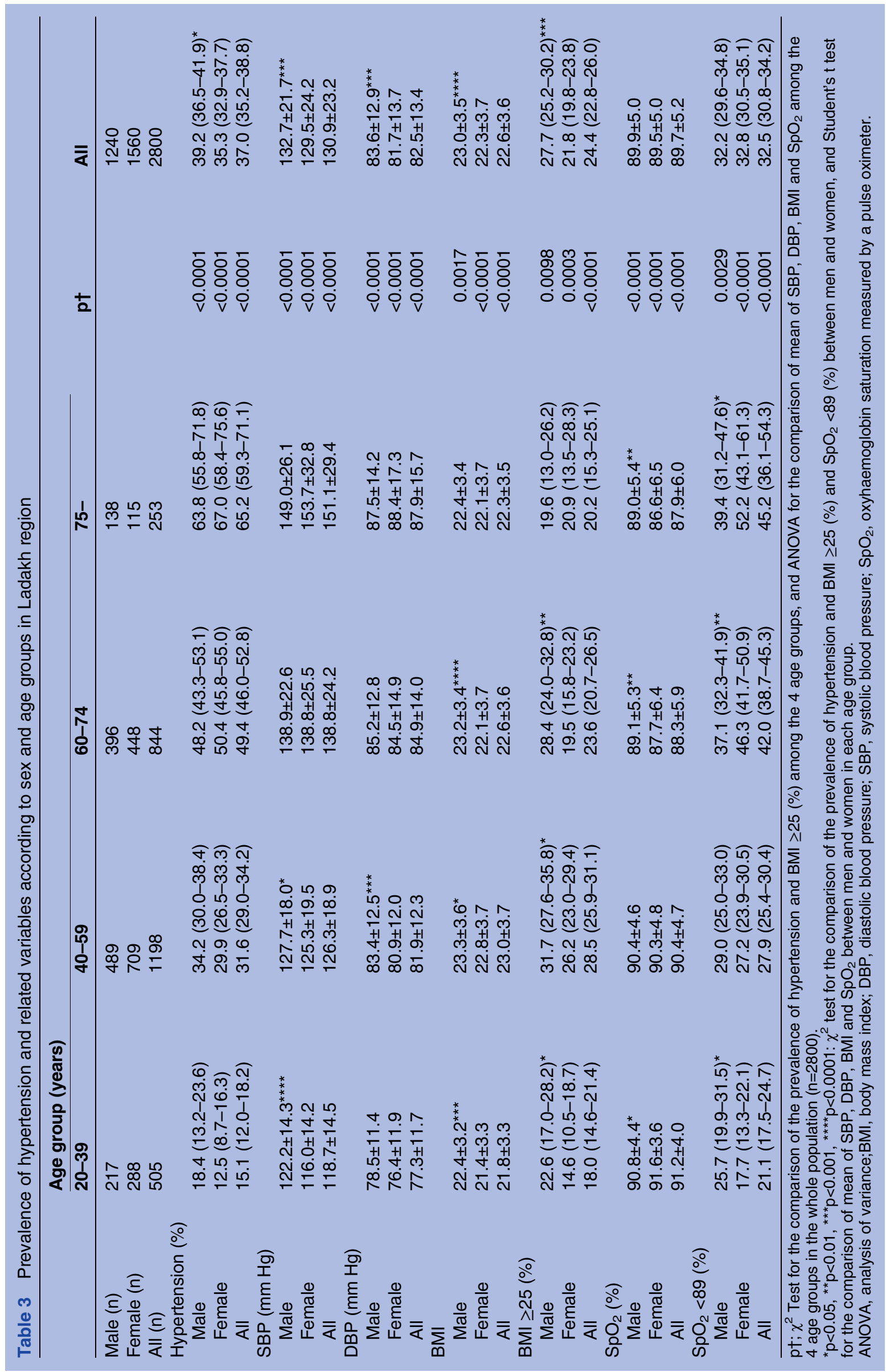




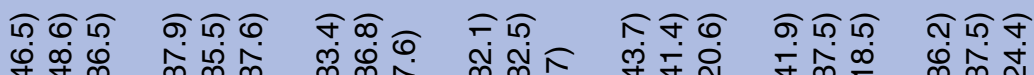

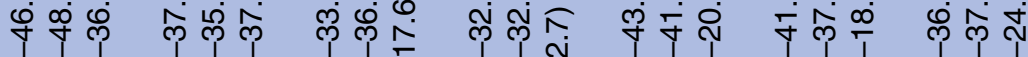

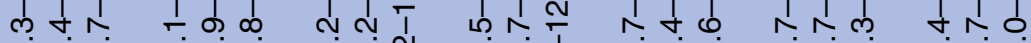

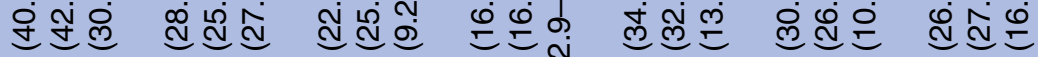

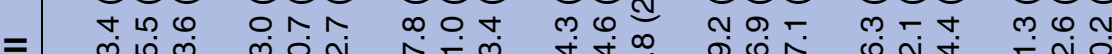

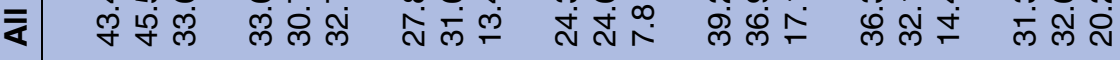

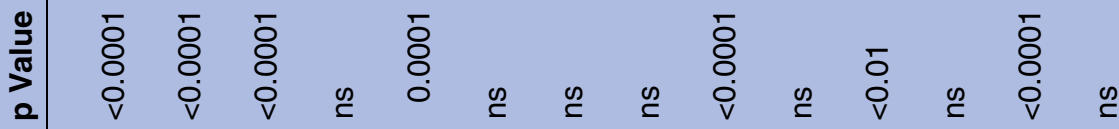

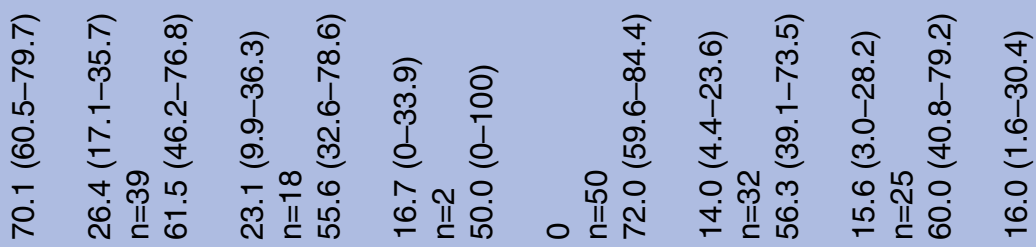

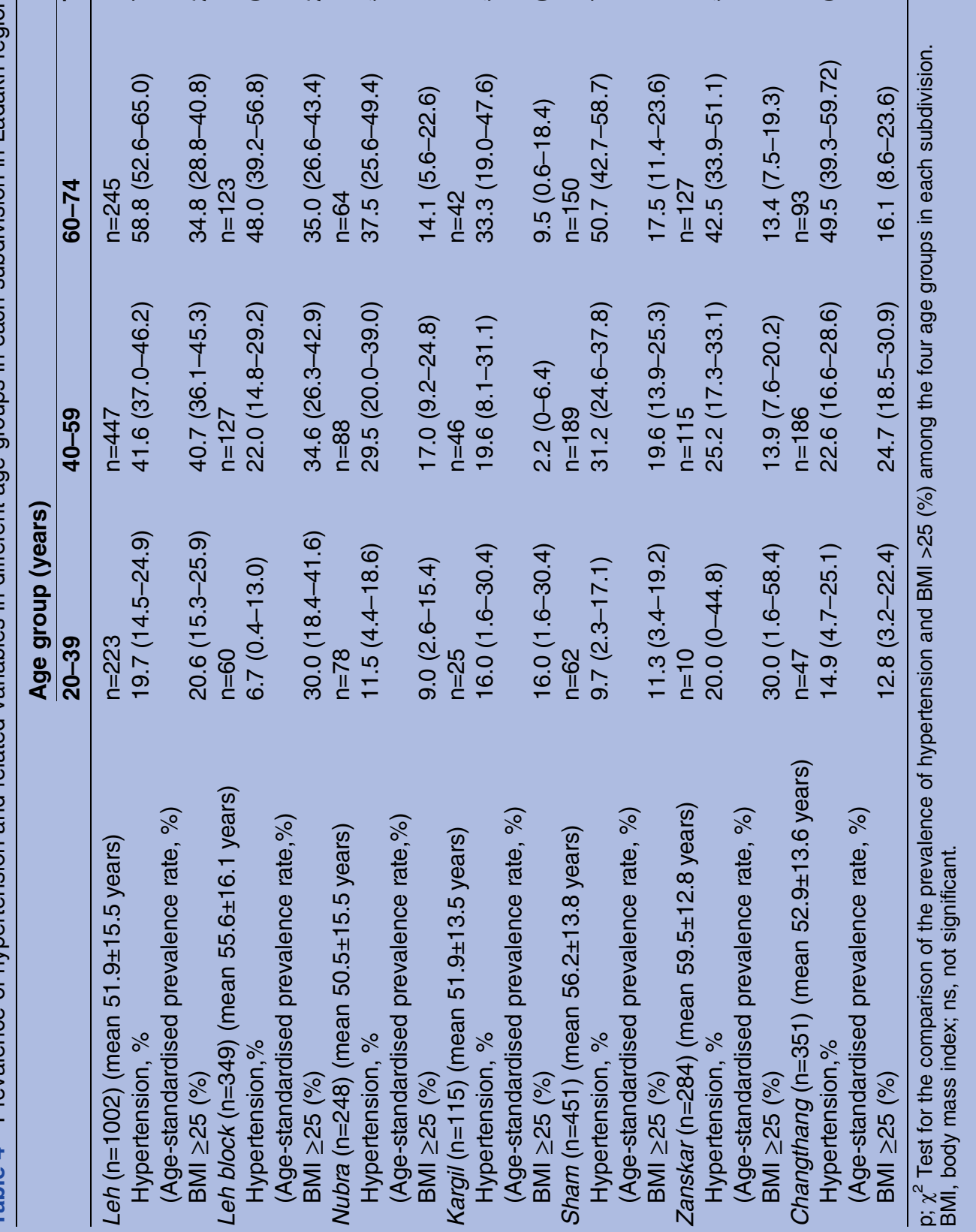









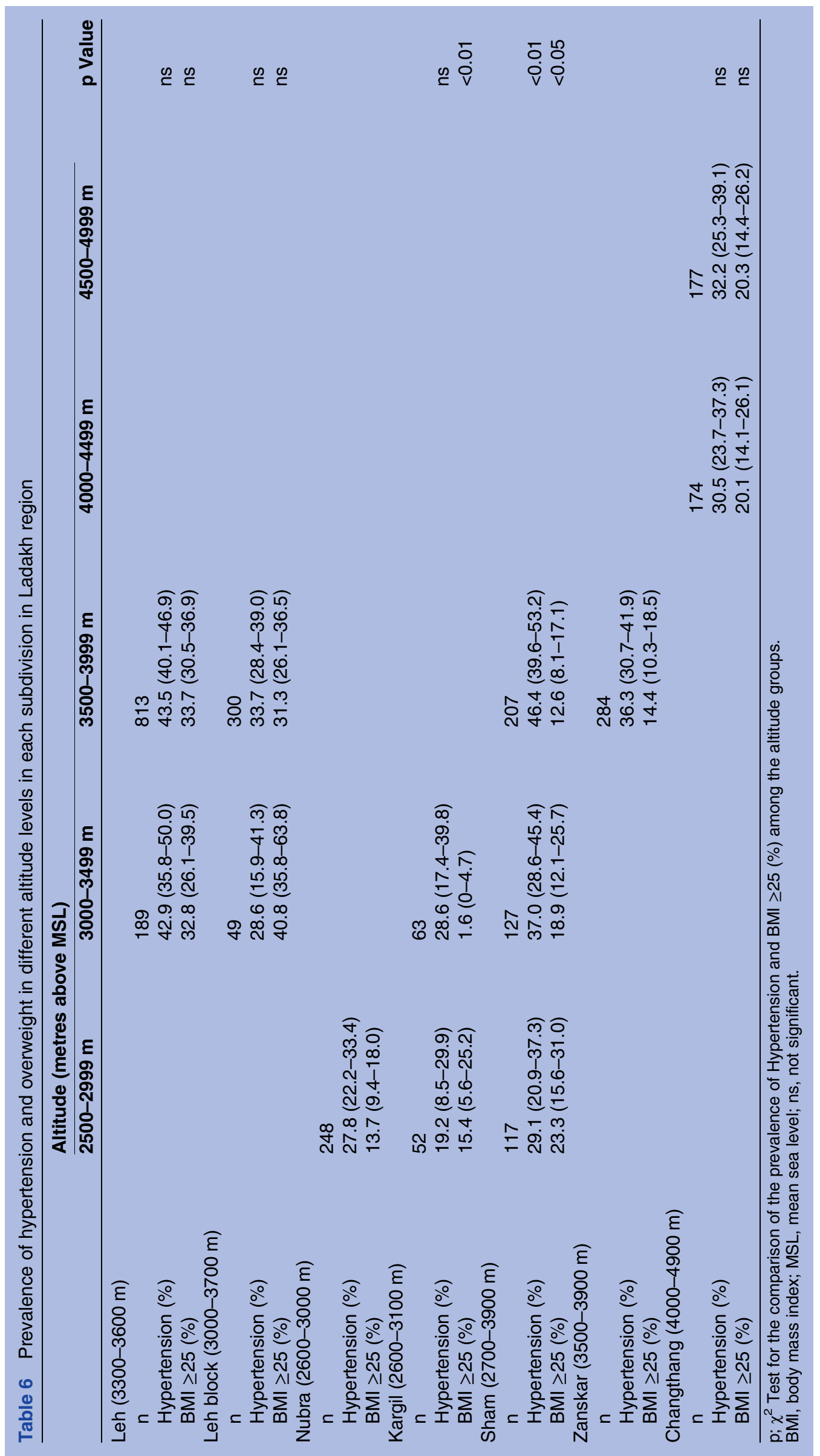




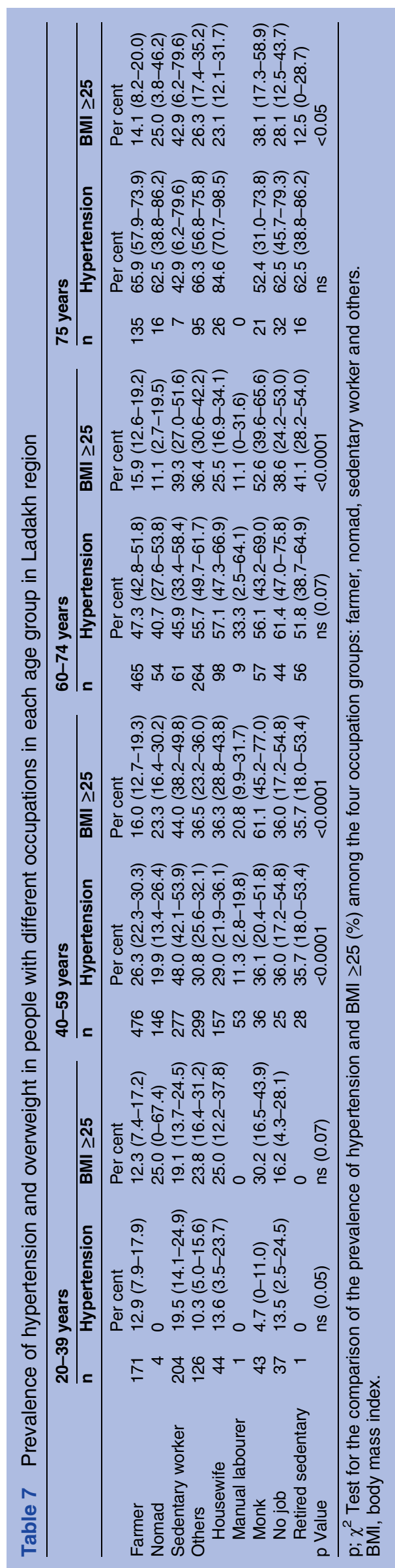

Table 8 shows the prevalence of hypertension and overweight comparing among dwellers in rural areas and Leh town and rural-to-urban migrants. The prevalence of hypertension and overweight was highest in migrants settled in Leh (hypertension/overweight; $48.3 \% / 40.9 \%$ ) followed by dwellers in Leh town $(41.1 \% / 30.2 \%)$ compared with those in rural areas (33. $5 \% / 15.3-19.3 \%)$. The percentage of engagement in occupations was shown in each participant group.

There was a difference in the prevalence of hypertension between Tibetan and Ladakhi nomads. The lowest prevalence of hypertension in spite of a higher prevalence of overweight was shown in Tibetan nomads $(\mathrm{n}=76) \quad$ (hypertension/overweight; 19.7\%/39.5\%) compared with Ladakhi nomads $(\mathrm{n}=144) \quad(31.9 \% / 10.4 \%)$ living at higher altitude $(4000-4900 \mathrm{~m})$.

The effects of altitude, occupation and dwelling area on hypertension were analysed in all the participants by multiple logistic regression adjusted with age, sex and overweight in models 1-3 (table 9). In model 1, the altitude ranges of 3000-3499 (OR 1.78) and 3500-3999 (OR 1.42) were significantly associated with high prevalence of hypertension compared with 2500-2999 (m) adjusted with age, sex and obesity. However, the higher range of 4000-4499 or 4500- was not associated with hypertension. In model 2 with further adjustment by occupation, the altitude ranges of 3000-3499 (OR 1.62) and 3500-3999 (OR 1.34) and the highest range of 4500- (OR 2.57) became significantly associated with hypertension. Sedentary workers had a higher association (OR 1.56) compared with farmers, while nomads had a lower association (OR 0.42). In model 3, with further adjustment by dwelling area, the altitude range of 3000-3499 (OR 1.44) and the highest altitude range of 4500- (OR 2.69) kept significant association with hypertension independent of occupation and dwelling area. People dwelling in Leh town (OR 1.92) and migrants from Changthang (OR 1.70) were significantly associated with a high prevalence of hypertension compared with those dwelling in rural areas.

\section{DISCUSSION}

In the current study, we found that one-third of the population is at a higher risk of hypertension. As table 3 shows, the prevalence of hypertension tends to increase with age in both genders. Average SBP and DBP in men less than 60 years of age was found to be higher than in age-matched women. This is consistent with the prevalence of adult hypertension in a US population, ${ }^{22}$ in a south Indian Chennai urban population study ${ }^{23}$ and in rural and urban communities of Rajasthan. ${ }^{24}$ The cause of lower blood pressure in women below 60 years may be due to hormonal effects in women during this age, that is, premenopausal women having a lower arterial blood pressure than age-matched men. ${ }^{25}$ This may also be due to the effect of obesity, as the prevalence of overweight in men was higher in people under 75 years 
Table 8 Prevalence of hypertension and related variables in different dwelling areas in Ladakh region

\begin{tabular}{|c|c|c|c|c|}
\hline \multirow[b]{2}{*}{$\mathbf{n}$} & \multirow[b]{2}{*}{$\begin{array}{l}\text { Rural areas } \\
1798\end{array}$} & \multicolumn{2}{|l|}{ Urban: Leh town } & \multirow[b]{2}{*}{ p Value } \\
\hline & & $\begin{array}{l}\text { Dwellers in } \\
\text { Leh town } \\
683\end{array}$ & $\begin{array}{l}\text { Migrants from } \\
\text { Changthang } \\
319\end{array}$ & \\
\hline Age (years) & $54.9 \pm 14.6$ & $49.0 \pm 15.9$ & $58.2 \pm 12.3$ & $<0.0001$ \\
\hline Hypertension (\%) & 33.5 (31.3-35.7) & $41.1(37.4-44.8)$ & $48.3(42.8-53.8)$ & $<0.0001$ \\
\hline $\mathrm{BMI} \geq 25(\%)$ & 19.3 (17.5-21.1) & $30.2(26.8-33.6)$ & $40.9(35.5-46.3)$ & $<0.0001$ \\
\hline $\mathrm{SpO}_{2}$ & $88.8 \pm 5.6$ & $90.7 \pm 4.2$ & $92.3 \pm 3.2$ & $<0.0001$ \\
\hline $\mathrm{SpO}_{2}<89(\%)$ & $40.6(38.3-42.9)$ & 21.7 (18.6-24.8) & $10.1(6.8-13.4)$ & $<0.0001$ \\
\hline Altitude (m) & $3543.2 \pm 534.1$ & $3449.0 \pm 86.9$ & $3491.9 \pm 39.6$ & $<0.0001$ \\
\hline \multicolumn{5}{|l|}{ Occupation (\%) } \\
\hline Farmer & $66.8(64.6-69.0)$ & $6.3(4.5-8.1)$ & $0.9(0-1.9)$ & \\
\hline Nomad & $12.0(10.5-13.5)$ & 0 & $1.3(0.1-2.5)$ & \\
\hline Sedentary & $8.0(6.7-9.3)$ & $47.0(43.3-50.7)$ & $26.6(21.8-31.4)$ & \\
\hline Others & $13.2(11.6-14.8)$ & $46.7(43.0-50.4)$ & $71.2(66.2-76.2$ & \\
\hline Housewife & $2.6(1.9-3.3)$ & $27.2(23.9-30.5)$ & $28.8(23.8-33.8)$ & \\
\hline Manual labourer & 0 & $0.9(0.2-1.6)$ & $17.9(13.7-22.1)$ & \\
\hline Monk & $6.8(5.6-8.0)$ & $5.0(3.4-6.6)$ & $0.3(0-0.9)$ & \\
\hline No job & $1.5(0.9-2.1)$ & $5.9(4.1-7.7)$ & $22.3(17.7-26.9)$ & \\
\hline Retired sedentary & $2.3(1.6-3.0)$ & $7.8(5.8-9.8)$ & $1.9(0.4-3.4)$ & \\
\hline
\end{tabular}

compared with women. The epidemiology of hypertension on the Tibetan plateau carried out by Sun and shinfu, ${ }^{12}$ however, reports a higher prevalence of hypertension in women in all age groups. This difference in results might be influenced by there being more females in their cohort, as well as possible differences in obesity that are not shown in their report.

Though age-standardised prevalence of hypertension in Leh block $(30.7 \%)$ was not high compared with other rural areas (24.6-36.8\%), higher prevalence of hypertension in Leh town (45.5\%) and higher prevalence of overweight in Leh block $(32.7 \%)$ and Leh town $(33.6 \%)$ were found compared with other rural areas (overweight; 7.8-20.2\%). The high prevalence of overweight may be brought about because Leh block is somehow a more developed subdivision than the others in this study. Urbanisation can change the lifestyle of the people and their diet habits, which may result in obesity and high prevalence of hypertension. Dietary quantity intake as assessed by our nutritionist (Y.K) by a $24 \mathrm{~h}$ recall method showed that energy intake was higher in Leh town (2305 kcal in men and $1933 \mathrm{kcal}$ in women) as compared to higher altitude at Changthang (2029 kcal in men and $1802 \mathrm{kcal}$ in women). Variety of food intake as assessed by 11-item Food Diversity Score Kyoto (FDSK-11) was higher in Leh $(6.7 \pm 1.8)$ as compared to higher altitude Changthang $(6.1 \pm 1.5) .^{26-28}$ Economic conditions, traditional food culture and a harsh environment with limitation of resources affect energy intake and food diversity. In urban Leh and Leh block, the economic condition of the population is better. Bread, mutton, rice, pulses, vegetables, thukpa and eggs are the main dietary foods, with snacks of sweet tea, biscuits, and fast food. Such a diet increases their calories, resulting in high BMI, and increases their salt intake, contributing to the higher prevalence of hypertension. One of the villages in Leh block, Stok, was a study centre in the Indian component of the Intersalt study, ${ }^{29}$ an international study to determine the relationship of blood pressure with dietary ingredients, particularly sodium and potassium. Urinary sodium (means (and SD) calculated for men aged 20-39, men aged 4059, women aged 20-39, and women aged 40-59 and then averaged over age and sex groups) was $203.7 \mathrm{mmol} / 24 \mathrm{~h}$ (75.0) and urinary potassium was 47.0 (19.2) $\mathrm{mmol} / 24 \mathrm{~h}$ with a poor potassium sodium ratio. Although the data pertain to the year 1988, there is every reason to surmise that the situation which persists as a condition of socioeconomic improvement without parallel improvement in health awareness prevails even today. There is a recent report on the effect of using a low-sodium, high-potassium salt substitute for Tibetan highlanders with hypertension. ${ }^{30}$

Domkhar valley in Sham subdivision situated along the Domkhar stream is about $25 \mathrm{~km}$ long and divided into three hamlets of different altitudinal contour and diversified environment. Paba, rice, bread, thukpa, sku, kholak and the local beverage chang are the main diets. Meat is rarely available. Fresh fruit is available in plenty in lower Domkhar and at some places in middle Domkhar, but none in upper Domkhar due to its highaltitude location (Altitude $3800 \mathrm{~m}$ ). Prevalence of hypertension is very high here $(39.1 \%)$ among the rural subdivisions. The prevalence of hypertension, especially in Sham subdivision, was as high as that in Leh town in the old age group above 60 years (Sham: $56.0 \%$ vs Leh town: 


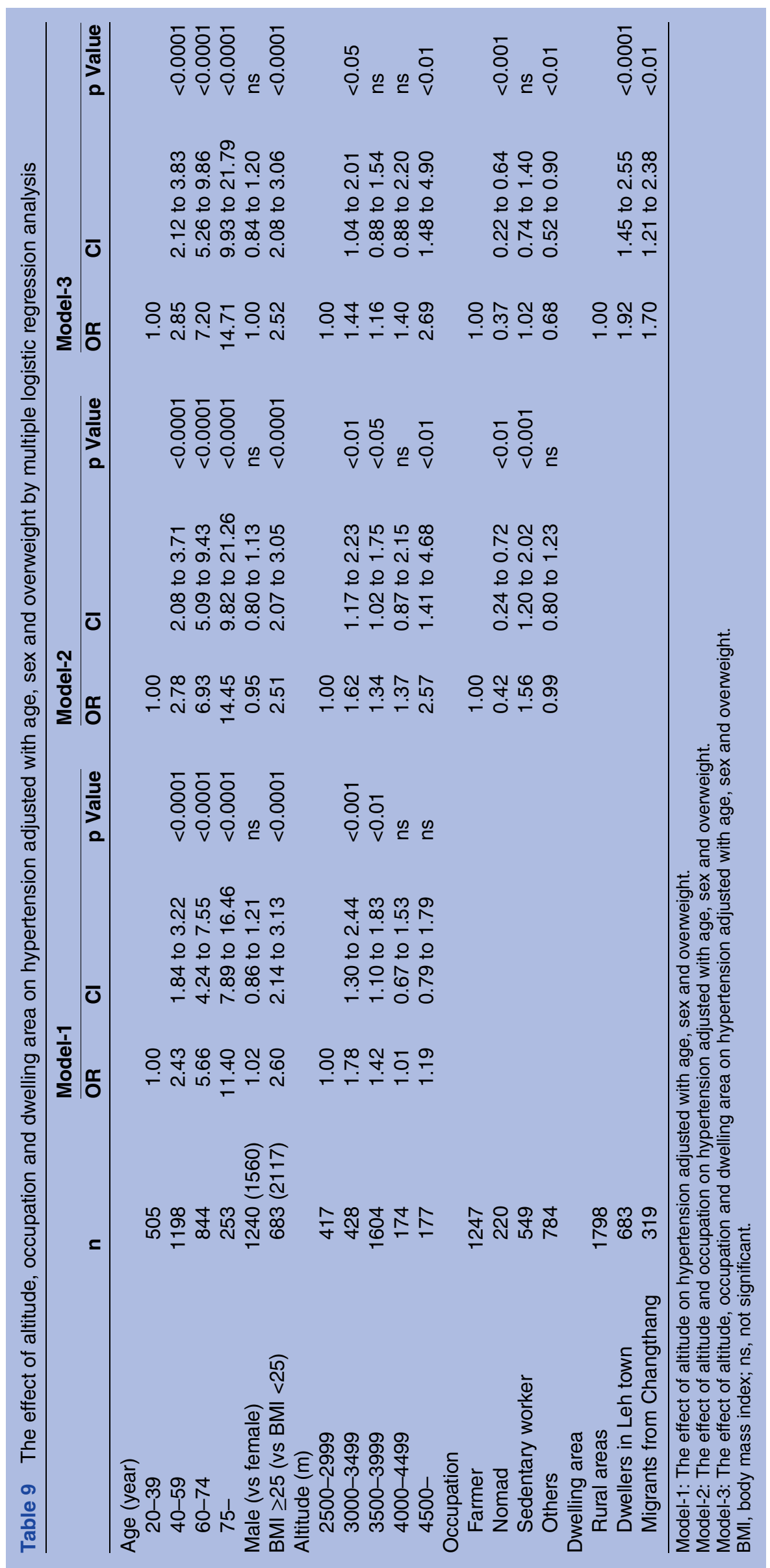


$61.7 \%)$ and in the higher altitude level of 3500-3999 (Sham: $46.4 \%$, Leh town: $43.5 \%$ ) in spite of a much lower rate of overweight in Sham (17.1\%) compared with Leh town $(33.6 \%)$. Different from people in the Leh block subdivision, people in Sham had much poorer availability of foods for a long time until recently and they may have vulnerability to the recent quick change of dietary habits, especially in older people and those dwelling in remote areas at higher altitude. We showed the high prevalence of impaired glucose tolerance $(35 \%)$ in old people in Domkhar compared with Tibetan people in Qinghai, China in the previous report. We also suggested that there may be a vulnerability to glucose intolerance brought on by recent changes in lifestyle in people with long-term backgrounds of economically traditional lifestyles with limited food resources. ${ }^{31}$

Mutton, rice, momo (mutton), thukpa (comprising of Atta, vegetable mostly dry and dry cheese), kholak (Barley flour with local tea) and paba (a mix of barley flour, wheat flour and grounded pea cooked in plain water with salt added to taste) are the main diets of the Changthang population in both Ladakhis and Tibetans. Taking snacks is not in their food culture, and nor are modern snack items available at that remote highaltitude region. A relatively lower prevalence of hypertension was observed in Changthang Tibetan natives (19.7\%) and Changthang Ladakhis (31.9\%) living at higher altitude (4000-4900 m).

Zanskar subdivision, located at an intermediate high altitude (3500-3900 $\mathrm{m})$, has a population mainly concerned with farming and cattle rearing. Butter tea, local beverage chang, thukpa, barley flour kholak, rice and pulses are the main dietary foods; meat is rarely eaten. Fresh fruit and vegetables are usually not available in Zanskar and Changthang. The crude prevalence of hypertension in Zanskar appears to be high (36.3\%) but age-standardised prevalence $(32.1 \%)$ was the same as in other rural areas, as the mean age was highest in Zanskar (table 4).

Modernised sedentary workers, rural-to-urban migrants, and dwelling in urban area population (Altitude 3300-3600 m) had a higher prevalence of hypertension and increased BMI as compared to the rural population. Previous reports support our hypothesis of highlanders' vulnerability to hypertension by socioeconomic globalisation. ${ }^{12-14}$ 31-34 A higher prevalence of hypertension was reported in Tibetans compared with immigrant Hans in the Tibetan plateau, with the prevalence being greater in the urban population around Lhasa than in the rural population. ${ }^{12}$ In another report, a longitudinal survey was carried out in the prevalence of hypertension in people over 15 years in different ethnic groups in China in 1991 and 2002. The prevalence of hypertension in Tibetan people increased from $17.8 \%$ (in 1991) to $24.7 \%$ (in 2002), which was the highest compared with the other seven ethnic groups including Han (from $11.3 \%$ to $16.2 \%$ ). ${ }^{32} \mathrm{~A}$ recent report showed that the prevalence of hypertension ( $\mathrm{SBP} \geq 140$ or $\mathrm{DBP} \geq 90$ or treatment) in 1289 Tibetan highlanders (Lhasa and suburbs; $3700-4200 \mathrm{~m}$ ) aged 18 and more was $39 \% .^{13}$ Another report showed that the prevalence of hypertension in 692 Tibetan highlanders (rural area of Lhasa; $3700 \mathrm{~m}$ ) aged $30-80$ years was $37 \% \quad(\mathrm{SBP} \geq 130$ or DBP $\geq 85$ or treatment). ${ }^{14}$ The prevalence of hypertension was close to our result of $37 \%$ and higher than that of Chinese lowlanders aged 20 years and more $(27 \%$ in 2007-2008). ${ }^{15}$ Blood pressure in 332 highlanders in Leh (13-81 years old, mean 50 years) was compared with those in U town, Hokkaido, Japan (24-79 years, mean 56.8) in 2004. Higher DBP and a larger increase in blood pressure with age were observed in people living at a high altitude, as compared with Japanese living at a low altitude. ${ }^{35}$ Younger people, but not adults and elderly people, among Tibetan immigrants from Leh to the lowlands in India were reported to have higher blood pressure compared with those living in the highlands. Measurements of adiposity had a significant effect on $\mathrm{BP}^{33}$ The prevalence of hypertension was higher $(72.7 \%)$ in Tibetan highlanders in Shangrila (Altitude: $3300 \mathrm{~m}$ ) compared with lowlanders in Jing Hong $(57.0 \%)$ and Tosa $(59.9 \%)$. There was a significant association between living in an urban area with a higher prevalence of hypertension and obesity in younger people under 60 years compared with those living in a rural area. ${ }^{34}$ Younger people may be more vulnerable to hypertension by a quick modernised lifestyle change. Also in our report, a higher prevalence of hypertension in Leh town $(44.7 \%)$ was observed, especially in the middle-aged group of 40-59 years, compared with other areas (19.6-30.7\%).

A higher OR of altitudes from 3000 to $3999 \mathrm{~m}$ compared with an altitude below $3000 \mathrm{~m}$ was observed after adjustment with age, sex and overweight. One reason may be socioeconomic factor, as this altitude level was compatible with that of the urban area of Leh town and urban dwellers had a higher rate of hypertension and obesity by lifestyle change compared with rural dwellers. Another reason may be the effect of high altitude itself, as the dwellers in Sham subdivision at the altitude of 3000-3999 $\mathrm{m}$ had a higher prevalence of hypertension in spite of a lower prevalence of overweight compared with those dwelling below $3000 \mathrm{~m}$. The highest prevalence in older people was shown at a higher altitude over $4000 \mathrm{~m}$. Moreover, the prevalence of hypertension rose closely with altitude remarkably in farmers $(\mathrm{p}<0.001)$, mildly in sedentary workers $(\mathrm{p}=0.09)$ and insignificantly in nomads (table 5). That is the reason why the higher altitude range of 3000-3999 and 4500- (OR 2.18) kept significant association with hypertension after adjustment with age, occupation or dwelling area by the multivariate analysis, which also supports the effect of high altitude itself to hypertension.

The limitation of this paper is that it did not look into the genetic factors, as environmental and genetic factors may contribute to regional and racial variations of blood pressure and prevalence of hypertension. Genetic 
evidence for high-altitude adaptation in Tibetan people was reported recently. ${ }^{3637} \mathrm{~A}$ relatively lower prevalence of hypertension in spite of a higher one of overweight in Changthang Tibetan natives (hypertension/overweight; $19.7 \%$ vs $31.9 \% / 39.5 \%$ vs $10.4 \%$ ) compared with Changthang Ladakhi living at higher altitude (4000$4900 \mathrm{~m}$ ) was observed in our report. The association between the hypoxic adaptation gene and hypertension should be studied further. The strength of this study is that it looked into most of the environmental factors known to influence hypertension in the population of different distinct geographical subdivisions of a highaltitude region. This study showed the influence of ageing, overweight, modernised sedentary occupations and rural-to-urban migration and dwelling in urban areas to hypertension as well as the effect of high altitude on hypertension by multivariate analysis.

The conclusion reached is that like everywhere else in the world, hypertension prevalence in a high-altitude population has multifactorial aetiology. Our study shows that age, gender, socioeconomic factors, culture, race and changing lifestyle play a big role with the effect of high altitude itself on the high prevalence of hypertension.

\author{
Author affiliations \\ ${ }^{1}$ Ladakh Institute of Prevention, Leh-Ladakh, India \\ ${ }^{2}$ University of California, San Diego, California, USA \\ ${ }^{3}$ Sonam Norboo Memorial Hospital, Leh-Ladakh, India \\ ${ }^{4}$ Defence Institute of High Altitude Research, Defence Research \& \\ Development Organization, Leh-Ladakh, India \\ ${ }^{5}$ Defence Institute of Physiology \& Allied Sciences, Defence Research \& \\ Development Organization, Delhi, India \\ ${ }^{6}$ Center for Southeast Asian Studies, Kyoto University, Kyoto, Japan \\ ${ }^{7}$ Hakubi Center for Advanced Research, Kyoto University, Kyoto, Japan \\ ${ }^{8}$ Department of Medicine, Tokyo Women's Medical University, Medical Center \\ East, Tokyo, Japan \\ ${ }^{9}$ Graduate School of Asian and African Area Studies, Kyoto University, Kyoto, \\ Japan \\ ${ }^{10}$ National Institute for Agro-Environmental Sciences, Ibaragi, Japan \\ ${ }^{11}$ Faculty of Education and Regional Studies, University of Fukui, Fukui, Japan \\ ${ }^{12}$ Research Institute for Humanity and Nature, Kyoto, Japan
}

Acknowledgements The authors thank all the participants for their consent and participation. The authors thank our LIP staff, Mr Tsering Motup, Mrs Rigzin Dolma, Miss Ishey Lhamo (Laboratory Technicians), Mrs Sherab Dolma, Miss Rinchen Dolma (Office secretaries) and Miss kunznag Dolma (ECG technician and instrument upkeep staff) for their quality work while travelling to all the difficult subdivisions of Ladakh. The authors thank $\mathrm{Mr}$ Chewang Motup and Mrs Yangdu Motup of Rimo Expedition and Mr None P Wangchuk of LIP for their invaluable help in logistics.

Contributors TN, TS, KO were involved in the study concept and design. TN, NT, NA, PT, IA, TC, VKS, PR, SBS, YK, EF, KS, MI, RS, MN, TY, TT, KO, KO were involved in the field study and data acquisition. TS, VKS, TN, YK, KM, $\mathrm{KO}$ were involved in the analysis and interpretation of the data. TN was involved in the drafting of manuscript. KO, TS, VKS were involved in the critical revision of manuscript.

Funding TN received research support from the Tata Institute of Social Sciences Mumbai India, Research Institute for Humanity and Nature, Kyoto, Japan, DIHAR (Defence Institute of High Altitude Research), and DIPAS (Defence Institute of Physiology \& Allied Sciences). KO received research support from High Altitude Project in Research Institute for Humanity and Nature, Kyoto, Japan.
Competing interests None declared.

Patient consent Obtained.

Ethics approval Institutional review board of Ladakh institute of prevention and the District ethical committee, Leh, Ladakh and Research Institute for Humanity and Nature, Kyoto, Japan.

Provenance and peer review Not commissioned; externally peer reviewed.

Data sharing statement No additional data are available.

Open Access This is an Open Access article distributed in accordance with the Creative Commons Attribution Non Commercial (CC BY-NC 4.0) license, which permits others to distribute, remix, adapt, build upon this work noncommercially, and license their derivative works on different terms, provided the original work is properly cited and the use is non-commercial. See: http:// creativecommons.org/licenses/by-nc/4.0/

\section{REFERENCES}

1. Siques $P$, Brito J, Banegas JR, et al. Blood pressure responses in young adults first exposed to high altitude for 12 months at $3550 \mathrm{~m}$. High Alt Med Biol 2009;10:329-35.

2. Parati G, Bilo G, Faini A, et al. Changes in $24 \mathrm{~h}$ ambulatory blood pressure and effects of angiotensin II receptor blockade during acute and prolonged high-altitude exposure: a randomized clinical trial. Eur Heart J 2014;35:3113-22.

3. Monge MC, Monge CC. High altitude diseases; mechanism and management. Springfield, IL: Charles C Thomas, 1966:62-70.

4. Somers VK, Mark AL, Abboud FM. Potentiation of sympathetic nerve responses to hypoxia in borderline hypertensive subjects. Hypertension 1988;11:608-12.

5. Levine BD, Zuckerman JH, deFilippi CR. Effect of high-altitude exposure in the elderly: the Tenth Mountain Division study. Circulation 1997;96:1224-32.

6. Baggish AL, Wolfel EE, Levine BD. Cardiovascular system. In: Swenson ER, Bartsch P, eds. High altitude: human adaptation to hypoxia. New York: Springer, 2014:103-40.

7. Luks AM. Should travelers with hypertension adjust their medications when traveling to high altitude? High Alt Med Biol 2009;10:11-15.

8. Velasco A, Vongpatanasin W, Levine BD. Treating hypertension at high altitude: the quest for a magic bullet continues. Eur Heart $J$ 2014;35:3083-4.

9. Dasgupta DJ. Study of blood pressure of a high altitude community at Spiti (4000m). Indian Heart J 1986;38:134-7.

10. Baker PT. The biology of high altitude peoples. Cambridge, New York: Cambridge University Press, 1978:335-6.

11. Toselli S, Tarazona-Santos E, Pettener D. Body size, composition, and blood pressure of high-altitude Quechua from the Peruvian Central Andes (Huancavelica, 3,680m). Am J Hum Biol 2001;13:539-47.

12. Sun SF. Epidemiology of hypertension on the Tibetan Plateua. Hum Biol 1986;58:507-15.

13. Chen $\mathrm{W}$, Liu $\mathrm{Q}$, Wang $\mathrm{H}$, et al. Prevalence and risk factors of chronic kidney disease: a population study in the Tibetan population Nephrol Dial Transplant 2011;26:1592-9.

14. Sherpa LY, Deji, Stigum $\mathrm{H}$, Chongsuvivatwong $\mathrm{V}$, et al. Prevalence of metabolic syndrome and common metabolic components in high altitude farmers and herdsmen at $3700 \mathrm{~m}$ in Tibet. High Alt Med Biol 2013;14:37-44.

15. Gao Y, Chen G, Tian H, et al., China National Diabetes and Metabolic Disorders Study Group. Prevalence of hypertension in China: a cross-sectional study. PLOS ONE 2013;8:e65938.

16. The Census Organization of India. The Indian Census. 2011. http:// www.census2011.co.in/census/district/621-leh.html, http://www. census2011.co.in/census/district/622-kargil.html

17. Tata institute of social sciences and Ladakh automonous hill development council. Micro level plans (MLP 2010)- Leh District, District report, p11-17. http://download.tiss.edu/fap/gyurja/gyurja reports/mlp_combined_1.pdf

18. Imai $\mathrm{Y}, \mathrm{Abe} \mathrm{K}$, Sasaki $\mathrm{S}$, et al. Clinical evaluation of semiautomatic and automatic devices for home blood pressure measurement: comparison between cuff-oscillometric and microphone methods. $J$ Hypertens 1989;7:983-90.

19. Imai $Y$, Satoh H, Nagai K, et al. Characteristics of a communitybased distribution of home blood pressure in Ohasama in northern Japan. J Hypertens 1993;11:1441-9. 
20. Okumiya K, Matsubayashi K, Wada T, et al. A U-shaped association between home systolic blood pressure and four-year mortality in community-dwelling older men. J Am Geriatr Soc 1999;47:1415-21.

21. Chobanian AV, Bakris GL, Black HR, et al. Seventh report of the Joint National Committee on Prevention, Detection, Evaluation, and Treatment of High Blood Pressure. Hypertension 2003;42:1206-52.

22. Burt VI, Whelton P, Rocella EJ, et al. Prevalence of hypertension in the US adult population: Results of the Third National Health and Nutrition examination survey, 1988-1991. Hypertension 1995;25:305-13.

23. Shantirani CS, Pradeepa R, Deepa R, et al. Prevalence and risk factors of hypertension in a selected south Indian populationThe Chennai urban population study. J Assoc Physicians India 2003;51:20-7.

24. Gupta R, Sharma AK, kapoor A, et al. Epidemiological studies and treatment of hypertension in rural and urban community of Rajasthan. JAPI 1997;45:863-4

25. Dubey RK, Oparil S, Imthurn B, et al. Sex hormones and hypertension. Review. Cardiovasc Res 2002;53:688-708.

26. Kimura $Y$, Fukitomi E, Ishikawa $M$, et al. Association between total energy intake and diabetes in Ladakh. Himalayan Study Monograph 2013;14:39-45.

27. Kimura Y, Matsubayashi K, Sakamoto R, et al. Food diversity and its relation to health of highlanders-comparison of urban and rural settings in Qinghai and Ladakh. Himalayan Study Monograph 2012;13:86-93.

28. Kimura $\mathrm{Y}$, Wada $\mathrm{T}$, Ishine $\mathrm{M}$, et al. Food diversity is closely associated with activities of daily living, depression, and quality of life in community-dwelling elderly people. J Am Geriatr Soc 2009;57:922-4.

29. Intersalt cooperative research group. INTERSALT: an international study of electrolyte excretion and blood pressure. Result for 24 hour urinary sodium and potassium excretion. BMJ 1988;297:319-28.

30. Zhao X, Yin X, Li X, et al. Using a low-sodium, high-potassium salt substitute to reduce blood pressure among Tibetans with high blood pressure: a patient-blinded randomized controlled trial. PLOS ONE 2014;9:e110131.

31. Okumiya K, Sakamoto R, Kimura Y, et al. Diabetes mellitus and hypertension in elderly highlanders in Asia. J Am Geriatr Soc 2010;58:1193-5.

32. $\mathrm{Hu}$ YS, Yao CH, Wang WZ, et al. Survey on the prevalence of hypertension in different ethnic groups in China in 2002. Wei Sheng Yan Jiu 2006:35:573-5.

33. Vikal T, Ranjan G. Blood pressure variation among Tibetans at different altitudes. Ann Hum Biol 2007;34:470-83.

34. Okumiya $\mathrm{K}$, Ishine $\mathrm{M}$, Kasahara $\mathrm{Y}$, et al. The effects of socioeconomic globalization on health and aging in highlanders compared to lowlanders in Yunnan, China, and Kochi, Japan. Ecol Res 2011;26:1027-38.

35. Otsuka K, Norboo T, Otsuka Y, et al. Effect of aging on blood pressure in Leh, Ladakh, a high-altitude $(3524 \mathrm{~m})$ community, by comparison with a Japanese town. Biomed Pharmacother 2005;59 (Suppl 1):S54-7.

36. Beall CM, Cavalleri GL, Deng L. Natural selection on EPAS1 (HIF2alpha) associated with low hemoglobin concentration in Tibetan highlanders. Proc Natl Acad Sci USA 2010;107:11459-64.

37. Simonson TS, Yang Y, Huff CD. Genetic evidence for high-altitude adaptation in Tibet. Science 2010;329:72-5. 